\title{
メマイ患者の統計的観察
}

\author{
（大阪市大メマイ外来より）
}

田中 耕一。井元 俊夫・松原 律子

\section{Statistical Observations on Patients with Vertigo and Dizziness}

\author{
Koichi Tanaka, Toshio Imoto, Ritsuko Matsubara \\ (Osaka City Univ.)
}

Statistical observations were made of outpatients with vertigo and dizziness seen in the Dept. of Otorhinolaryngology, Osaka City University from 1972 to June 1977. The results are reported herein:

1) Those with vertigo and dizziness included $4-6 \%$ of the total number of outpatients. However, the number of Equilibrium function tests carried out in our patients was extremely large, as many more outpatients were seen in our clinic as compared with the number in other universities.

2) There was almost no difference in the number of males and females with vertigo and dizziness. Occurrences were in the descending order of $40>30>50>20$.

3) About $70 \%$ of the patients were introduced by other physicians. They were mainly otorhinolaryngologists outside the hospital or physicians in the Depts. of Orthopedics, Internal Medicine and Neurosurgery in our hospital.

4) When we investigated statistics of diseases, we found that Meniere's disease acounted for about $10 \%$ and an extremely large number of patients with "cerebral vascular insufficiency" (our term) and patients with trauma at the head and neck were encountered.

5) Fifty percent of all patients revealed abnormalities in blood pressure, and $60 \%$ belonged to III and IV field as to CMI.

\section{はじめに}

近年社会機構が複雑になるに従って，メマイを訴える患者は増加の傾向にある。しかしメマイ， 平衡障害を訴える患者の適確な診断およびその治療を行なうことは時として困難なととがある．昭 和 47 年より大阪市立大学附属病院耳鼻咽喉科にメマイ外来を設置すると共に, 当科外来の診療形態 屯変更し, その他の特殊外来（アレルギー，中耳疾患）手同時に開設した。メマイ外来の最大の目 的は，「1人 1 人の患者の訴えを時間をかけて聞く」ということにあり，待ち時間を少なくするた めに予約制をとっている。 そこで今回は昭和 47 年以降における当科で平衡機能検査を行なった患者 について，疾患別，年度別等の統計的観察を行なったので報告する． 


\section{I . 外来診療システム}

当科ではメマイ患者の診療は田中が，検査は 検査技師の松原が，次いで統計処理について井 元が参面している関係上，当科を訪机る患者は まず耳鼻咽喉科外来で耳鼻咽喉頭部の視診の 上, (メマイ発作を起としているとか, その他 特殊な場合を除いて）図 1 の如き, 側頭骨レ線 血液検查（梅毒反応，血清脂質，一般検血，肝 機能等), 平衡機能検査（立ち直り反射加ら視 運動刺激検査まで），CM I と検査の予約を行 ない，検査後病歴を再聴取して総合判定を行な っている，その後他科紹介, 紹介医, 紹介科へ の返事の要あるものは行ない, 当科で Followup できるものはメマイ外来にて時間予約制で Follow-up するシステムをとっている. 一般 的に二次平衡機能検査といわれるあのまで，当 科でルーチン検査とするととには検査時間や経 費等で多少問題があるが，(1)メマイ外来徒事

\section{めまい患者の検査システム}

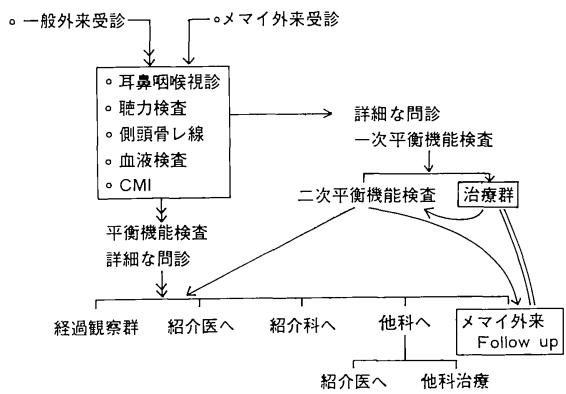

する医師の少ないとと. (2)原因不明のメマイ患 者が多いので，単純なる末梢性眩量患者は少な く視運動刺激検査まで施行してはじめて診断が つくことが多いととの点から二次平衡機能検査 まで，ルーチン検査としている。

\section{II. 統 計 的 観 察}

\section{(1)平衡機能検査数}

表 1 の如く平衡機能検査は昭和 47 年から昭和 49年までは 300 前後であったが，50年の 4 月よ り前述の如く, 平衡機能検査の方法を統一して 以来，メマイ，平衡障害のない患者一例えば側 弯症加慢性中耳炎の術前検査一も行なうように なり，表 2 の如く，半年間に約 250 名近くの検 査を施行している．現在のシステムでは一人の 検查時間が約 2 時間近くかかり，一日に 3 人ま でしか施行できない．従って検査技師の疲労の 問題，あるいは休日，休暇等も考えれば 1 年間 に約 $500 \sim 550$ 位が, 最大の検查数であり, 待ち 時間の問題，検查数の制限等，人員の増加がな ければ，限度に達していると考えられるのでて れらの点が今後の問題と考えられる.

(2)×マイ患者の性別，年令

表 1,2 亿見られる如く男女差は過去 5 年間 の統計ではほ之んど見られない，表 3 の如く年 令別では40才代が一番多く, 次いで30才代, 50
才代，20才代と続くが，40才代は社会的に重要 な地位を占める年代であり，多くのストレスが かかり，また体調の変化する年代であることあ 考えれば当然のととと考える。10才代がかなり 多いのは，メマイはほとんどないが，整形外科 よりの側弯症の症例が多いことが考えられる。 さらに最近では，平均年令の高令化のためとも 考えられるが70才代以上の年令層の増加も見ら れるようである。

(3)受診状況

原則的には，大学病院はいかなる診療科ある いは如何なる病気にかかわらず紹介されて受診 するのが望ましいと著者は考学るが，当大学の 立地条件やその他種々のととにより，すべてが 紹介されたものではない. 表 4 の如く, 当科を 受診したメマイ患者は70\%弱から75～6\%まで 紹介患者である.しかし逆に30\%から24～5\% の患者はメマイを訴える場合，他科を受診せず 耳科を受診したととは，メマイのある時はまず 
表 I 平衡機能検査数

昭和 47 年 51 年

\begin{tabular}{c|r|r|r|r|r|r}
\hline \hline & 昭和 47 年 & 48年 & 49 年 & 50 年 & 51 年 & 計 \\
\hline 人 数 & 307 & 298 & 311 & 333 & 506 & 1755 \\
\hline 男 & 170 & 157 & 160 & 163 & 263 & 913 \\
女 & 137 & 141 & 151 & 170 & 243 & 842 \\
\hline 外 来 & 6,747 & 6,677 & 7,193 & 7,484 & 7,944 & 36,045 \\
総 数 & $(4.55 \%)$ & $(4.46 \%)$ & $(4.32 \%)$ & $(4.45 \%)$ & $(6.37 \%)$ & $(4.87 \%)$
\end{tabular}

表 2 平衡機能検査数 昭和 50 年 7 月 52 年 6 月迄

\begin{tabular}{|c|c|c|c|c|c|c|}
\hline & & 昭和 $50.7 \sim 50.12$ & $51.1 \sim 51.6$ & $52.7 \sim 51.12$ & $52.1 \sim 6$ & 計 \\
\hline 人 & 数 & 213 & 244 & 262 & 230 & 949 \\
\hline \multicolumn{2}{|c|}{ 男 } & 100 & 135 & 128 & 126 & 489 \\
\hline \multicolumn{2}{|c|}{ 女 } & 113 & 109 & 134 & 104 & 560 \\
\hline 外 & 来 & 3,355 & 4,532 & 3,412 & 4,969 & 16,268 \\
\hline 総 & 数 & $(6.35 \%)$ & $(5.38 \%)$ & $(7.68 \%)$ & $(4.63 \%)$ & $(5.83 \%)$ \\
\hline
\end{tabular}

表 3 メマイ患者の年令

\begin{tabular}{|c|c|c|c|c|c|c|}
\hline 年令 年度 & 昭和47年 & 48年 & 49年 & 50 年 & 51年 & 計 \\
\hline 10才以下 & 0 & 4 & 3 & 3 & 4 & 14 \\
\hline 10〜19才 & 19 & 21 & 11 & 21 & 36 & 108 \\
\hline 20〜29才 & 48 & 46 & 39 & 45 & 57 & 235 \\
\hline 30～39才 & 81 & 57 & 64 & 68 & 117 & 387 \\
\hline 40 く49才 & 77 & 85 & 98 & 91 & 125 & 476 \\
\hline 50〜59才 & 48 & 45 & 49 & 62 & 117 & 321 \\
\hline 60〜69才 & 29 & 30 & 43 & 33 & 33 & 168 \\
\hline \multirow[t]{2}{*}{ 70才以上 } & 5 & 10 & 4 & 10 & 17 & 46 \\
\hline & 307 & 298 & 311 & 333 & 506 & 1,755 \\
\hline
\end{tabular}

表 4 受診状況

\begin{tabular}{|c|c|c|c|c|c|}
\hline & S 47年 & 48年 & 49年 & 50年 & 51年 \\
\hline 紹介あり & $\begin{array}{r}233 \text { 名 } \\
(75.9 \%)\end{array}$ & $\begin{array}{r}207 \text { 名 } \\
(69.5 \%)\end{array}$ & $\begin{array}{r}203 \text { 名 } \\
(74.0 \%)\end{array}$ & $\begin{array}{r}229 \text { 名 } \\
(68.7 \%)\end{array}$ & $\begin{array}{r}\text { 386名 } \\
(76.3 \%)\end{array}$ \\
\hline 紹介なし & $\begin{array}{r}74 \text { 名 } \\
(24.1 \%)\end{array}$ & $\begin{array}{r}91 \text { 名 } \\
(30.5 \%)\end{array}$ & $\begin{array}{r}81 \text { 名 } \\
(26.0 \%)\end{array}$ & $\begin{array}{r}104 \text { 名 } \\
(31.3 \%)\end{array}$ & $\begin{array}{r}120 \text { 名 } \\
(23.7 \%)\end{array}$ \\
\hline 合棓 & 307名 & 298名 & 311名 & 333名 & 506名 \\
\hline
\end{tabular}


表 5 紹介患者の内訳け

\begin{tabular}{|c|c|c|c|c|c|c|}
\hline & 47年 & 48年 & 49年 & 50年 & 51年 & 合 計 \\
\hline A. 他医より紹介 & $\begin{array}{r}66 \text { 名 } \\
(28.3 \%)\end{array}$ & $\begin{array}{r}58 \text { 名 } \\
(28.0 \%)\end{array}$ & $\begin{array}{r}56 \text { 名 } \\
(24.3 \%)\end{array}$ & $\begin{array}{r}65 \text { 名 } \\
(28.4 \%)\end{array}$ & $\begin{array}{r}108 \text { 名 } \\
(28.0 \%)\end{array}$ & $\begin{array}{r}3533 \text { 名 } \\
(27.5 \%)\end{array}$ \\
\hline \multirow{4}{*}{$\begin{array}{l}\text { 耳鼻咽喉科医 } \\
\text { 内科医 } \\
\text { 整形外科医 } \\
\text { その他 }\end{array}$} & 16名 & 25 名 & 13名 & 29 名 & 56 名 & \\
\hline & 24名 & 23名 & 33名 & 27名 & 38名 & \\
\hline & 26名 & 8名 & 7名 & 9名 & 9名 & \\
\hline & 0名 & 2名 & 3名 & 0名 & 5名 & \\
\hline B. 他科より紹介 & $\begin{array}{r}148 \text { 名 } \\
(63.5 \%)\end{array}$ & $\begin{array}{r}141 \text { 名 } \\
(68.1 \%)\end{array}$ & $\begin{array}{r}167 \text { 名 } \\
(72.6 \%)\end{array}$ & $\begin{array}{r}157 \text { 名 } \\
(68.6 \%)\end{array}$ & $\begin{array}{r}272 \text { 名 } \\
(70.5 \%)\end{array}$ & $\begin{array}{r}885 \text { 名 } \\
(68.9 \%)\end{array}$ \\
\hline \multirow{2}{*}{$\begin{array}{l}\text { 内科 } \\
\text { 脳外科 }\end{array}$} & 74名 & 44名 & 55 名 & 56名 & 73名 & \\
\hline & 38名 & 52名 & 58名 & 48名 & 87名 & \\
\hline 整形外科 & 21名 & 26名 & 29名 & 33名 & 88名 & \\
\hline 神経科 & 4名 & 5名 & 6名 & 6名 & 7名 & \\
\hline その他 & 11名 & 14名 & 19名 & 14名 & 17名 & \\
\hline \multirow{3}{*}{ C. その他の紹介 } & 19名 & 8 名 & 7 名 & 7 名 & 6 名 & 47名 \\
\hline & $(8.2 \%)$ & $(3.9 \%)$ & $(3.1 \%)$ & $(3.0 \%)$ & $(1.5 \%)$ & $(3.6 \%)$ \\
\hline & 233名 & 207名 & 230名 & 229名 & 386名 & 1, 285名 \\
\hline
\end{tabular}

耳科へという考え方が多少なりとも普及したの ではないかと考える。さらに紹介患者の内訳け は表 5 の如くである。院外の先生よりの紹介が 平均 $27.5 \%$, 院内の各科よりの紹介が $68.9 \%$, その他の紹介 $36 \%$ あるあ。その他の紹介は医師 でない人からの個人的紹介である，紹介患者の 院外の耳科医からの紹介では 50 年，51年 では $44.6 \%$ から 50 強に達し, 当科のメマイ外来が認 識されて来たためと考えられる．また院内各科 からの紹介では，当初は内科からの紹介が半数 を占めていたが，脳外科の充実のためか整形外 科加らの側弯症, 頸性眩暈等の検査依頼が次第 に増加し，昭和51年では整形外科，脳外科，内 科と順位が逆転し，内科の紹介の占める割合は 26.8\%となっている，いずれにしても紹介医と しては，耳鼻科医，内科医，脳外科医，整形外 科医が圧倒的に多く，神経科医，眼科医よりの 紹介は極めて少数である。

\section{(4)疾患別統計}

前述した如く，昭和 47 年にメマイ外来を設置 後，その後約 3 年間はまず患者の訴えを充分に 聞くということで，検查の手順や内容方法等に
ついては，暗中模索の状態であったが，昭和 50 年 4 月より，メマイ検査の方法を統一したので 50 年 7 月から 52 年 6 月末までの 2 年間に打ける 患者の疾患扝よび検查結果について検討を加え た。メマイ患者の疾患別統計は表 6 の如くであ る。主として内耳由来のものではメニエル病は メマイ患者の約 $10 \%$ 分弱であり外来総数から見れ ば0.53\%である。次いで中耳炎性内耳炎である が，てれはすべてがメマイを訴えたでのはな く，慢性中耳炎の手術目的で入院した際，術前 に平衡機能検査を施行し，その結果内耳障害と 考える屯のも含んでいる，次いで内耳循環不全 症，突発性難聴である．主として中枢性メマイ と考えられるあのでは，我々の提唱する「いわ ゆる脳循環不全症」および血压異常が極めて多 く，243例（26.5\%） 飞達すると考えられる. 次いで多いのは頭頸部外傷患者で男女差が著明 にみられる。次いで惟骨動脈循環不全症および 䁰性メマイと続く。猶，椎骨動脈循環不全症や 頸性メマイと考えられるもののうち, 病歴より 外傷のあるものは頭頸部外傷とした。 
表 6 めまい外来受診患者の男女別笑患の頻度

(昭和 50 年 7 月～昭和 52 年 6 月)

\begin{tabular}{|c|c|c|c|c|c|}
\hline 主として内耳由来のもの & $\begin{array}{c}\text { 男 } \\
\text { 例数 }(\%)\end{array}$ & $\begin{array}{c}\text { 女 } \\
\text { 例数 }(\%)\end{array}$ & 主として中枢性のもの & $\begin{array}{c}\text { 男 } \\
\text { 例数(\%) }\end{array}$ & $\begin{array}{c}\text { 女 } \\
\text { 例数 }(\%)\end{array}$ \\
\hline$x=エ ル$ 病 & $39(7.9)$ & $48(10.4)$ & いわゆる脳循環不全 & $102(20.9)$ & $141(30.7)$ \\
\hline 中耳炎性内耳炎 & $37(7.6)$ & $32(7.0)$ & （血圧異常も含む） & & \\
\hline 内耳循環不全症 & $23(4.7)$ & $42(9.1)$ & 頭頸部外傷 & $114(23.3)$ & $44(9.6)$ \\
\hline 突発性難聴 。 & $15(3.0)$ & $13(2.8)$ & 椎骨動脈循環不全 & $27(5.5)$ & $29(6.3)$ \\
\hline 良性発作性頭位眩量 & $11(2.2)$ & $7(1.5)$ & 頸性めまい & $24(4.9)$ & $25(5.4)$ \\
\hline 突発性前庭障害 & $16(3.3)$ & $8(1.8)$ & 側弯性 & $4(0.8)$ & $17(3.7)$ \\
\hline （前庭神経炎も含む） & & & 聴神経腫演 & $4(0.8)$ & $6(1.3)$ \\
\hline 薬物中毒 & $5(1.0)$ & $9(2.0)$ & 小脳疾患 & $8(1.6)$ & $2(0.4)$ \\
\hline 迷路振盪症 & $4(0.8)$ & $2(0.4)$ & 脳血管障害 & $7(1.4)$ & $2(0.4)$ \\
\hline 内耳梅毒 & $4(0.8)$ & $2(0.4)$ & 先天性眼振 & $1(0.2)$ & $2(0.4)$ \\
\hline ベル麻痺ハント症候群 & $2(0.4)$ & $2(0.4)$ & その他の中枢障害 & $36(7.4)$ & $25(5.4)$ \\
\hline $\begin{array}{l}\text { 原因不明の迷路障害 } \\
\text { (その他の原因も含む) }\end{array}$ & $4(0.8)$ & $2(0.4)$ & （原因不明も含屯） & $50(1.4)$ & $20(3.4)$ \\
\hline 耳管狭窄疑い & $11(2.2)$ & $4(0.9)$ & 心因性めまい & $6(1.2)$ & $9(2.0)$ \\
\hline
\end{tabular}

表 7 聴力検査の結果

(昭和 50 年 7 月～昭和 52 年 6 月)

\begin{tabular}{|c|c|}
\hline & 例数 $(\%)$ \\
\hline 正 & $395(41.6)$ \\
\hline 異＜wide>常 & $551(58.1)$ \\
\hline \multicolumn{2}{|l|}{ 感音性難聴 } \\
\hline 片 側 & $149(15.7)$ \\
\hline 両 側 & $224(23.6)$ \\
\hline \multicolumn{2}{|l|}{ 伝音性難聴 } \\
\hline 片 側 & $52(5.4)$ \\
\hline 両 側 & $22(2.3)$ \\
\hline \multicolumn{2}{|l|}{ 混合性難聴 } \\
\hline 片 側 & $110(11.6)$ \\
\hline 両 側 & $46(4.8)$ \\
\hline
\end{tabular}

表 8 立ち直り反射検查

（昭和 50 年 7 月～昭和 52 年 6 月)

\begin{tabular}{ll|r}
\hline & & 例 数 $(\%)$ \\
\hline 正 & 常 & $161(17.0)$ \\
異 & 常 & $767(80.1)$ \\
& 軽度障害 & $343(36,1)$ \\
& 中等度障害 & $380(40.0)$ \\
& 高度障害 & $44(4.6)$
\end{tabular}

(5)検査成績について

a. 恥力検查

949名中946名について施行しているが，両側 共正常域にある例は，41.6\%であった。異常群 は58.1\%であり，一側または両側が感音性難聴 を示すむのは，39.3\%，同様に伝音難聴または 混合難聴を示すあのは24.1\%である。但し両側 が各々感音, 伝音, 混合難聴のいずれかで両側 異なる場合があるので症例数は異常例 551症例 よりあ増加している，但し異常者群であ今回は メマイとの関係については検討していないの で，てれらの難聴群がメマイと関係あるから゙う 加不明である。今後検討の予定である。また興 味あることは, 自覚的な難聴の有無と他覚的な 難聴との間に時として大きなずれがあるとと で，他覚的な中等度難聴でも，高令になると自 覚的に難聴を訴えない人があるととである.

b. 立ち直り反射

施行例は 928例でそのうち80\%に異常をみと め, 軽度障害例 $36.1 \%$, 中等度障害例 $40.0 \%$, 高度障害 $4.6 \%$ あ゙り，多くの異常を示し検査 時期にもよると考えられるが, 平衡障害の検出 
表 9 偏倚検査

(昭和50年 7 月～昭和 52 年 6 月)

\begin{tabular}{cc|c|c}
\hline & & 上 肢 & 下 \\
\hline 正 & 常 & $752(79.2)$ & $675(71.1)$ \\
\hline 異 & 常 & $169(17.8)$ & $255(25.8)$
\end{tabular}

（）内は\%

表10 異常眼運動検査

(昭和 50 年 7 月～昭和 52 年 6 月)

\begin{tabular}{l|r}
\hline \hline & 例 \\
\hline 数 $(\%)$ \\
\hline 自発眼振のあるもの & $47(5.0)$ \\
注視眼振のあるもの & $24(2.5)$ \\
頭位眼振のあるもの & $211(22.2)$ \\
頭位変換眼振のあるもの & $169(17.8)$ \\
E N Gで初めて眼振を認めるもの & $165(17.4)$
\end{tabular}

表川 迷路刺激眼振検查

(昭和 50 年 7 月～昭和 52 年 6 月)

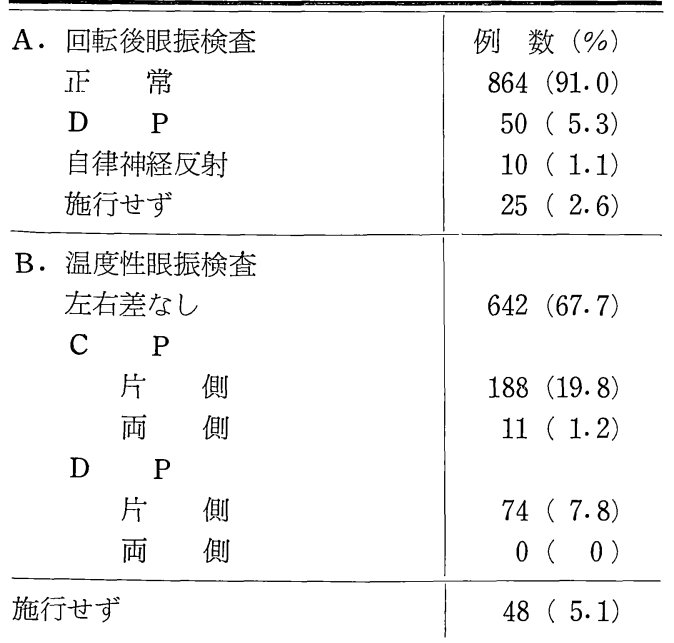

には極めて有効な検査法と考えられる。また経 過を知る場合にあ，手軽にできる検査であり， 動摇計を併用すれば，さらに有効な検査法であ ると考える。

\section{c. 偏倚検査}

表 9 の如く, 偏倚異常は立ち直り反射に比較 して極めて少ない。即ち上肢は $17.8 \%$ （921例 中），下肢は 25.8\%（930例中）の異常発現率
であり，下肢の偏倚異常を示すととが多いとと が考えら机る．乙れは他の報告例 $1 \sim 4$ 之同様 であるが，異常発兒率は生駒 ${ }^{1)}$ の $41.3 \%$, 若山 等 ${ }^{3)}$ の36.0\%よりは低いが，吉本等 ${ }^{4)}$ の $28 \%$ と ほぼ近い值を示す。乙れは検查時期および疾患 内容の相違によるものと考えられる。

d. 眼振検査

表10の如く, 注視眼振は $2.5 \%$ 亿, 自発眼振 は $5 \%$ ，頭位眼振のあるあのは $22.2 \%$, 頭位 変換眼振は17.8\%にみられた。乙れらはいずれ あ裸眼抒よびフレンツェル眼鏡下での観察でみ られたものである。その後 E N Gを使用して, 初めて眼振をとらえたものが $18.4 \%$ あり，合計 約 $40 \%$ 弱に眼振がみとめられると考えられる. 眼振の出現率の報告は種々あるが，加我等 ${ }^{51}$ に よれば正常人でも $41 \%$ に E N G 眼振を認める とされ，眼振の検討には，まず裸眼およびフレ ンツェル眼鏡下での観察を充分に行ない，その 後で E N Gでの記録を参考とするにとどめたい 之考えている。但し今回の我々の報告では, 頭 頸部外傷で頭位の動きが充分でなく，施行を拒 否する患者むあり, 眼振出現率はむう少し増加 するむのと考えられる。

\section{e. 迷路刺激検査}

従来より耳石の機能検査を除いて，半規管の 機能検査については多数考案されているが, 当 科では回転後眼振検査として 20 秒間 10 回転での 後眼振の観察, 温度眼振検査としては $30^{\circ}$ お び $44^{\circ} \mathrm{C} 20 \mathrm{ml}$ 注水の冷温交互試験を採用してい る。その結果は表11の如く, 回転後眼振検査の 異常出現率は極めて低くD Pを示すむの5.3\%， その他自律神経反射のみとめられたもの $1.1 \%$ ， 残りは左右差なしか事情により施行できなかっ た症例である。また冷温交互試験では異常出現 率は約 $30 \%$ 弱に異常がみられ, 従来の報告通り 冷温水交互試験の方がはるかに有効な検査之考 えられる。 その内訳けは機能低下群が $21.0 \%$ で あり，DP群は7.8\%にみられた。更に施行し ない48例は，鼓膜に穿孔のみられるものか術後 耳の症例である。 
猶 C P および D P の判定方法は

(1) C Pについては

$\frac{\mid （ \text { 右側迷路の反応時間の和 })- \text { (左側迷路の反応時間の和 }) \mid}{\text { 右側迷路の反応時間の和十左側迷路の反応時間の和 }} \times 100>20 \%$

(2) D Pについては

$\frac{\mid \text { （右側への眼振持続時間の和） }- \text { （左側への眼振持続時間の和） } \mid}{\text { 右側への眼振持続時間の和 }+ \text { 左側への眼振持続時間の和 }} \times 100>20 \%$ とした。

表 I2 視運動性反射検査

（昭和 50 年 7 月～炤和 52 年 6 月）

\begin{tabular}{|c|c|c|}
\hline \multicolumn{2}{|c|}{ A. 視標追跡検査 } & 例 数 $(\%)$ \\
\hline 正 & 常 & $394(48.4)$ \\
\hline \multirow[t]{5}{*}{ 異 } & 常 & $420(51.6)$ \\
\hline & 動摇型 & $245(30.1)$ \\
\hline & 脳幹型 & $110(13.5)$ \\
\hline & 小脳型 & $37(4.5)$ \\
\hline & 混合型 & $28(3.4)$ \\
\hline \multicolumn{3}{|c|}{ B. 視運動性眼振検查 } \\
\hline 正 & 裳 & $344(42.9)$ \\
\hline \multirow[t]{5}{*}{ 異 } & 常 & $458(57.1)$ \\
\hline & 視性D P & $53(6.6)$ \\
\hline & 解発不良 (錯倒型も含导) & \\
\hline & 片 側 & $151(18.8)$ \\
\hline & 両 & $254(31.7)$ \\
\hline
\end{tabular}

表13 めまい外来受診患者の素因 （昭和50年 7 月～炤和52年 6 月）

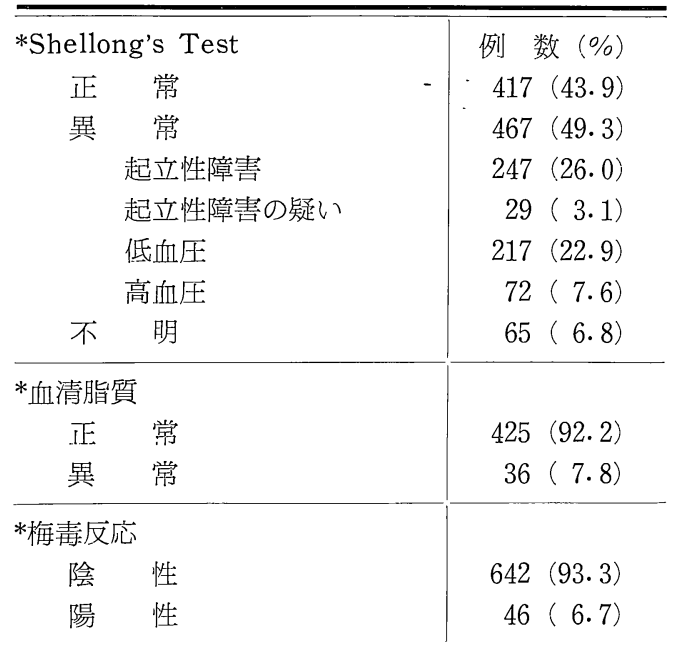

表|4メマイ外来受診患者のCM I

\begin{tabular}{cc|c}
\hline & & 例 数 $(\%)$ \\
\hline I & 型 & $53(19.1)$ \\
II & 型 & $58(21.0)$ \\
III & 型 & $74(26.7)$ \\
IV & 型 & $92(33.2)$
\end{tabular}

f. 視運動性反射検査

視運動性反射検查は当科では前述の如く，ル 一チン検査として施行しているが，㥢未施行例 屯多く，視標追跡検査では 949例中814例で135 例の未施行例が，視運動性眼振検査では施行例 802例で147例の未施行例がある。卡た今回は報 告していないが，視運動性後眼振になると，疲 労や呕気，呕吐のためにさらに未施行例は増加 している。視運動性眼振検査では，視標追跡検 査亡同様，パターン分析を試みているので，判 定者の主観が多少入る余地があると考えられ る．視標追跡検査では51.6\% 420例に異常パタ ーンがみられたが，動摇型即ち，小林ら6)の分 類のI 型もしくは】型にあたるものが， $30.1 \%$ ああり，乙れがすべて異常所見とするには，多 少問題もあるので，乙れらは今後検討の余地が あると考えられる．従って明らかな異常と考え られるものは21.4\%ट考えられる。また視運動 性眼振検査では57.1\%に異常群がみられた。乙 の場合も高令者の場合には，慎重に検討すべき であると考えている。

g. 全身的要因について

最近メマイ患者については，平衡機能検査の みならず，その全身的要因を検討する試みが多 くなって来ているが，当科でも，血圧測定，血 液検査等施行して検討している。 
(1)ショロングテスト

起立性調節障害の診断基準 ${ }^{7)}$ のうちメマイ患 者は異常群ではほとんど診断基準に合致する。 大症状，小症状を満たすと考えられる．従って 起立試験で脈圧の狭小化 $(16 \mathrm{mmHg}$ 以上), 収 縮期圧低下 $(21 \mathrm{mmHg}$ 以上), 脈拍増加（21 以上）のいずれかのあるものを起立性障害陽性 としている. 㥢心電図はごく少数例を除いて測 定していない。 その結果, 異常群49.3\%で, シ ョロングテスト陽性のもの $26.0 \%$ ，低血压 22.9 $\%$, 高血圧 $7.6 \%$ であり，乙れらの血圧異常群 が一つの原因となって脳循環不全症を引き起と すと考えられるので, 視標追跡検査や視運動性 哏振検査にも異常所見を示すと考えられる.

(2)血清脂質

血清脂質, 総コレステロール, リポ蛋白分画 トリグリセライド等を施行しているが，血清質 脂の増加により循環障害を来たすと考えられる ためである。しかし異常所見を呈したものは非 常に少なく，わずかに36例 $(7.8 \%)$ 亿異常所 見を示したのみである。

考

平衡機能検査の目的は坂田 ${ }^{10)} の$ 述べている 如く(1)中耳炎がある場合, 内耳その他に合併症 がないかどうか(2)患者の訴えるメマイは内耳疾 患によるものかどうか(3)患者の訴える耳鳴や難 聴は聴神経腫愓である可能性はないか(4)患者に みられる平衡障害やメマイは中枢疾患による可 能性はないかどうか，あれば病巣はどこにある かと考えられる，その目的に沿った平衡機能検 査を施行した上で, 病歴を詳細に聴取して診断 を下している. 当科のメマイ外来は数年間田中 が一人で経過を観察している，一人の医師が経 過を診るというととは独断的に陥入る危険性む 考えられるが，それと表裏一体で，いつも同じ 医師が診ることにより，メマイ患者は初診では 見せることがなかったその患者の生活環境等の バックグランドについて赤裸々に語るとともあ り，医療というものが単に病気を癒やすもので
(3)梅毒反応

一般的には梅毒反応陽性者が最近増加してい るといわれるが，今回の施行例では46例，（6.7 。）に陽性を示した。 そのうち, 内耳梅毒が疑 わ机たのは，わずかに6例であった。

\section{h. CMI について}

メマイ患者は多加少なかれ，精神的な要因 が存在するあのであり，そのために当科ではC MI を採用している． $\mathrm{Y}-\mathrm{G}$ テス卜む併用すべ きであるという考え方ああるが，CMIのみで 記入に20分以上かかるととを考えると，アンケ 一トに多数の時間をさくのは患者の苦痛を考 え, 我々はCM I のみ採用している。 その結果 表14の如く 277例中, III, IV 領域に入るものは 168例 59.9\%であった. 深町によれば健康正常 者でも IIII，IV 領域に入るものが $20 \%$ あるるし ている。また佐久間8 は鼻アレルギー患者では III，IV 領域のものは39\%としており，乙れらよ りもはるかに高值であり，また池見ら"9)の耳鳴 患者の検討によれば，III，IV 領域に入るもの57 \%とほぼ近い值を示していると考えられる。

\section{按}

なく，病人を癒やすという考えからすれば，医 師之患者の信頼関係を得られ，まことに都合の 良い場合もあると考えられる。特にメマイ患者 の場合は CM I のIII， IV 領域に約 $60 \%$ 近く入る ので，信頼関係のない治療は無意味であるとさ え考えている.てのような考えで数年間メマイ 外来にて多くの患者の経過を観察して来たが, メマイ患者の診断名についてはしばしば迷うこ とがある。そこでまず日常多くみられる疾患の 我々の診断基準を明らかにしておきたい。

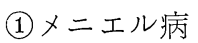

メニエル病の診断基準に関しては, 従来より 多くの報告 ${ }^{111414)}$ があるが，最近では厚生省メ ニエル病研究班の診断基準が多く使用されてい るようである。しかしての診断基準についても 多くの疑問が残る。乙のととについては別著に ゆずるとして, 現在使用している診断基準は下 
記の如くである。

(a)原因不明である。（メマイと関連する）

(b)メマイは発作的で，反復性がある。

(c)メマイに関連する難聴を認める。（聴力検 査時難聴がなくても, 発作時自覚的に難聴があ れば良い。また耳鴆のみの場合は含まないかメ ニエル病疑い例で経過観察する)

(d)難聴があれば内耳性聴聴

(2)突発性難聴

厚生省研究班の診断基準に従っている.

即与

(a)突然起こった感音性難聴.

(b)原因が不明である。

(c)眙暈加耳鳴を伴うあのあある。

(d)メマイ発作を繰り返したり, 聴力の改善悪 化を繰り返すことがない.

(3)突発性前庭障害（前庭神経炎）

(a)蝸牛症状は伴わない。(メマイと関連ある)

(b)反復性がない.

(c)メマイと関連のある神経障害がない.

(d)温度検査にて機能低下を認める。

(e)感冒その他ウィルスの感染を思わせるもの に引き続き起とるメマイ（前庭神経炎）， ある いは誘因なく発作性メマイが扣てる。（乫発性 前庭障害)

(4)良性発作性頭位眩暈

(a)頭位性メマイがある.

(b)メマイに蝸牛症状を伴わない.

(c)頭位，頭位変換眼振検査で迷路性の特徵を 持つ回旋性眼振をみとめる。

(d)メマイと関連ある内耳以外の障害を認めな (.

(5)内耳循環不全症

(a)メマイに関連した内耳以外の神経障害がな い.

(b)循環系の検查で血圧異常, 動脈硬化等をみ とめる。

(c)反復性がある.

(d)平衡機能検査にて前庭迷路の機能低下の所 見がある。
(6)わゆる脳循環不全症

過去, 平衡神経学会5) 6) 拈よび日耳鼻総会 ${ }^{17)}$ において報告して来たが，詳細は別著にゆずる として，大䀡を述べたい。即ち本疾患は椎骨動 脈の如き，大血管の障害でなく，微細な血管の 循環障害を示すあのである.

(a) 原因不明の中枢性眩暈である。

(b)低血圧, 高血圧, 起立性障害, 動脈硬化等 の循環系の障害がある.

(c)立ち直り反射障害がある.

(d)洔として方向交代性頭位眼振がみられる.

(e)脳神経症状がない。

以上が当科で採用している主たる疾患の診断 基準である。これらの診断基準に沿ってメマイ 患者を検討してみた。

(I) 平衡機能検查数

数に関しては, 当大学の立地条件，あるいは 最近ではメマイ外来が認識されることにより極 めて多い。吉本ら ${ }^{4)}$ は 2 年間で 741 例を, 若山 等 ${ }^{3)}$ ，大谷等 ${ }^{2)}$ は 7 年間で 1353 例を，生駒 ${ }^{1)}$ は 3 年間で 389 例を，松永ら ${ }^{18)}$ は 2 年間で769例を 報告している．昭和 47 ～50年までは吉本ら ${ }^{4)}$, 松永ら ${ }^{18)}$ の報告亡ほぼ同数と考えられるが，大 谷等 ${ }^{21}$, 生駒ら ${ }^{1)}$ の報告例より年間の検査数は 極めて多い．また51年に至って飛躍的に伸びて いるのは，慢性中炎例耳および側弯症例が加わ ったためむその一因と考えられる。また，各報 告例共外来患者数の $5 \sim 8 \%$ 間に存在するこ とを考えれば，他の原因の一つは総外来患者数 が極めて多いということが考えられる.

(II) 受診状況

当科外来を訪れるメマイ患者は年度に関係な く23〜30\%は直接受診患者である. 但し直接受 診患者でも，そのうちの何％かは近医の内科等 を受診して，紹介状なしで受診する患者も含ま れるので，生駒 ${ }^{1)}$, 大谷ら ${ }^{2)}$, 松永 ${ }^{18)}$ の報告 と同様，全般的には，メマイがあればまず内科 を受診する患者が多いと考えられる，紹介患者 の内訳けでも，院外からの紹介では耳鼻科医か らの紹介は漸増しているが，乙の院外からの紹 
介で47年度には整形外科医からの紹介が極めて 多いのは，頭頸部外傷専門医からであり，以後 減少したのはこの医師が退職したための特殊事 情によるものと考えられる。また院内加らの紹 介は内科医からの紹介が以前多かったが，最近 では脳外科および整形外科からの紹介の方が少 数だが多くなっている。乙れは脳外科や整形外 科の医師が平衡神経科学に注目している証と考 元られる。

(III) 疾患統計について

メマイ疾患の診断名については, 諸家の報告 によって, 異なる場合が多い, 吉本ら ${ }^{12)}$ は, 症 状による診断名を用いているし，各報告者の診 断に対する考え方も不明だが，メニエル病につ いての頻度は松永ら ${ }^{19)}$ の報告と略々一致してお り,メマイ患者の略々 $8 \sim 10 \%$, 総患者数の
$0.4 \sim 0.5 \%$ の頻度である. 中耳炎性内耳炎が多 いのは，あいかわらず慢性中耳炎というあのは 減少するととなく，抗生剂の発達が逆に病巣を

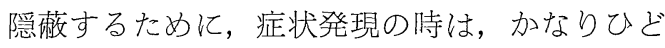
い状態にあることか，あるいは，手術前の病変 の拡がりを知る目的で，51年 4 月から，術前に 検査を施行しているととも関係があると思われ る. 松永 ${ }^{18)}$ の報告に非常に多い迷路性眩暈症 について, 我々は突発性前庭障害, 内耳循環不 全症と分類しており，さらにメ二エル病類似疾 患については，その一部はさらに，我々の提唱 する“いわゆる脳循環不全症、の中に含まれる 可能性も考えられる。また諸家の報告と比較し て異なる当科の立地条件によるものか頭頸部外 傷患者の多いととで，外傷患者の場合は後遺症 等の認定について種々問題がある場合が多い.

\section{ま と め}

昭和 47 年より昭和 52 年の間の当科メマイ外来受診者の統計的観察を行ない次の結果を得た.

(1)年間のメマイ検査数は外来総患者数の $4 \sim 6 \%$ であるが, 外来総患者数が他大学に比較して多 いので, メマイ検査数屯極めて多い.

(2)メマイ患者の男女差はほとんどなく，年令的に40才代が一番多く以下 $30 才$ 代，50才代，20才代 と続く.

(3)受診状況では約70\%近くが紹介患者であり，その紹介も院外では耳鼻科医からの紹介が，院内 では整形外科, 内科, 脳外科からの紹介が多い.

(4)疾患統計ではメニエル病はメマイ患者の約 $10 \%$ 内外，外来患者総数の約 $0.5 \%$ である．いわゆ る脳循環不全症か頭頸部外傷患者が極めて多い.

(5)検査結果では立ち直り反射異常に非常に高い異常発現率がみられる.

(6)素因の検査では血圧異常を示すものが，約50\%近くあるが，血清脂質異常，梅毒反応陽性者は 約 $6 〜 7 \%$ ある.

(7) CM I でIII，IV領域に入るものは約 $60 \%$ 近くある.

稿を終るに臨み御指導と御校閲を賜った恩師中井義明教授に深甚なる謝意を捧げます．またての小論文は中 井教授の就任を祝って作成されたものである.またての小論文を過ぐる日, 迷路に落ち込んだ筆者の進むべ き道をあたたかく導いていただいた岐皁大学, 時田喬教授に捧げます.

猶本論文の要旨は第176回日耳鼻大阪地方会（51年 2 月），第178回日耳鼻大阪地方会（51年 9 月）第39回耳 鼻咽喉科臨床会 (52年10月) で発表した。

文

1）生駒尚秋：わが教室における「めまい」外来の現 況. 耳鼻臨床 $66: 281 \sim 287,1973$.
献

2) 大谷晃, 他：わが教室におけるめまい患者の統計 的観察（第 1 報 めまい外来の現況之患者の一般 
特性）。耳鼻臨床 $67: 751 \sim 761,1974$.

3）若山徹, 他：わが教室におけるめまい患者の統計 的観察（第 2 報 平衡機能検查所見を中心に）. 耳鼻臨床 $67:$ 939 947, 1974.

4) 吉本裕, 他: めまい症例の統計的観察. 耳喉 $40: 885 \sim 894,1968$.

5 ) 加我君孝, 他：EN G の診断学的意義に関する検 討一正常例およびめまい. 平衡障害例における眼 振出現率の検討一. Equilibrium Res. 32：92〜 93, 1973.

6）小林淑子：神経耳科学的検査における視運動眼振 と視標追跡検查について. Equilibrium Res. $35: 65 \sim 67,1976$.

7 ) 市橋保雄, 他: 起立性調節障害. 中外医学社, 1974.

8 ) 佐久間龍良：鼻アレルギーの心身医学的研究. 耳展 $19: 123 \sim 155,1976$.

9 ) 池見酉次郎, 他：心身医学加見た耳鳴. 日耳鼻 $77: 827 \sim 828,1974$.

10）坂田英治編：映画「自発性異常眼運動の診断的意 義」より。

11）時田喬, 他：メニエール病ならびに類似疾患の診 断基準の検討. 耳鼻臨床 $68: 857 \sim 866,1975$.

12) 吉本裕：メニエール病の診断をめぐる諸問題一て とに診断名，診断基準について一。 耳鼻臨床 62: 1431 1438, 1969.
13) American Academy of Ophthalmology and Otology (Committee on hearing and equilibrium, chairman B. R. Alord): Meniere's disease : Criteria for diagnosis and evaluation of therapy for reporting. Trans. Am. Acad. Ophthalmol. Otolaryngol. $76:$ 1462 1464, 1972.

14）日本平衡神経科学会：診断名および診断基準の標 準化. Equilibrium Res. $26: 2 \sim 18,1970$.

15）田中耕一，他：いわ功る脳循環不全症の診断と治 療について. Equilibrium Res. 35: 73〜74, 1976.

16）永田清員, 他：いわ纤る脳循環不全症の診断と治 療について〔II Equilibrium Res. 36:141〜 142, 1977.

17）田中耕一, 他：いわゆる脳循環不全症の診断之治 療について.日耳鼻：80：1065, 1977.

18）松永喬，他：阪大におけるめまい患者の受診動 態. 耳鼻臨床 $68: 1205 \sim 1213,1975$.

19）松永喬, 他：メニエール病の臨床統計と臨床検査 成績. 耳鼻臨床 $68: 1367 \sim 1378,1975$.

$$
\begin{aligned}
& \text { 原稿到着: 昭和 } 53 \text { 年 } 7 \text { 月 } 14 \text { 日 } \\
& \text { 別刷請求先 : 田中耕一 } \\
& \text { † } 545 \text { 大阪市阿倍野区旭町 } 1-5-7 \\
& \text { 大阪市立大学医学部耳鼻咽喉科学教室 }
\end{aligned}
$$

